\title{
Inactivation of Rho Signaling Pathway Promotes CNS Axon Regeneration
}

\author{
Maxine Lehmann, ${ }^{1}$ Alyson Fournier, ${ }^{1}$ Immaculada Selles-Navarro, ${ }^{1}$ Pauline Dergham, ${ }^{1}$ Agnes Sebok, ${ }^{2}$ \\ Nicole Leclerc, ${ }^{1}$ Gabor Tigyi, ${ }^{2}$ and Lisa McKerracher ${ }^{1}$ \\ ${ }^{1}$ Département de Pathologie et Biologie Cellulaire, Université de Montréal, Succursale Centreville, Montréal, Québec H3C \\ 3J7, Canada, and 2Department of Physiology, University of Tennessee, Memphis, Tennessee 38163
}

Regeneration in the CNS is blocked by many different growth inhibitory proteins. To foster regeneration, we have investigated a strategy to block the neuronal response to growth inhibitory signals. Here, we report that injured axons regrow directly on complex inhibitory substrates when Rho GTPase is inactivated. Treatment of PC12 cells with C3 enzyme to inactivate Rho and transfection with dominant negative Rho allowed neurite growth on inhibitory substrates. Primary retinal neurons treated with C3 extended neurites on myelin-associated glycoprotein and myelin substrates. To explore regeneration in vivo, we crushed optic nerves of adult rat. After C3 treatment, numerous cut axons traversed the lesion to regrow in the distal white matter of the optic nerve. These results indicate that targeting signaling mechanisms converging to Rho stimulates axon regeneration on inhibitory CNS substrates.

Key words: retinal ganglion cells; optic nerve; Rho GTPase; microcrush lesion; C3 toxin; myelin-associated growth inhibitory proteins; MAG
Axons in the CNS of mammals do not regenerate after injury, and one barrier to regeneration is growth inhibition by CNS myelin (Schwab et al., 1993). Myelin inhibits axon growth because it contains several different growth inhibitory proteins. Myelinassociated glycoprotein (MAG) inhibits axon growth both in vitro and in vivo (McKerracher et al., 1994; Mukhopadhyay et al., 1994; Li et al., 1996; Schafer et al., 1996; Torigoe and Lundborg, 1998). Also, a different high molecular weight inhibitory activity is present in myelin (Caroni and Schwab, 1988). Neutralization of inhibitory activity with the IN-1 antibody allows some axons to regenerate in white matter (Schwab et al., 1993; Bregman et al., 1995). Inhibitory proteins expressed at the glial scar also block axon growth (McKeon et al., 1991). Therefore, multiple inhibitory proteins exist, and, for efficient axon regeneration in the adult CNS, it will be important to neutralize their inhibitory effects.

Although axons damaged in the CNS in vivo do not typically regrow, there have been some reports of long-distance axon extension in adult white matter. Such growth has been observed after transplantation of grafted neural tissue (Wictorin et al., 1990; Davies et al., 1994, 1997), but it is not completely understood. Suppression of the expression of inhibitory proteoglycans at the glial scar may be one determinant for successful neurite growth from transplanted neurons (McKeon et al., 1991; Davies

\footnotetext{
Received March 25, 1999; revised June 2, 1999; accepted June 14, 1999.

This work was supported by the Medical Research Council (MRC) (L.M. and N.L.), the National Sciences and Engineering Research Council of Canada (L.M.), and the National Science Foundation (G.T.). L.M. is a Fonds de la Recherche en Santé de Québec chercheur-boursier, and G.T. is an established investigator of the American Heart Association. M.L. was supported by an MRC postdoctoral fellowship and A.F. by a scholarship from Fonds pour la Formation de Chercheurs et l'Aide à la Recherche. We thank Ester Yu and Charles Essagian for technical help, Madeline Pool for help with primary cultures, and Benjamin Ellezam for help with computer graphics.

Drs. Lehmann, Fournier, and Selles-Navarro contributed equally to this work.

Correspondence should be addressed to Dr. Lisa McKerracher, Département de Pathologie et Biologie Cellulaire, Université de Montréal, C.P. 6128, Succursale Centreville, Montréal, Québec H3C 3J7, Canada.

Copyright (C) 1999 Society for Neuroscience 0270-6474/99/197537-11\$05.00/0
}

et al., 1997). In other cases, priming with neurotrophic factors to increase neuronal cAMP levels would make cells less susceptible to growth inhibition (Cai et al., 1999). For the regeneration of injured adult neurons, current strategies to foster axonal regrowth in myelinated regions of the CNS are to bypass myelinated tracts (David and Aguayo, 1981; Cheng et al., 1996), remove myelin (Keirstead et al., 1992), or use IN-1 antibody to block myelin inhibitors (Schnell and Schwab, 1990; Bregman et al., 1995). However, none of these methods is directed toward neuronal signaling mechanisms that regulate axon growth. Neurotrophins have been tested in vivo for their ability to help axons regenerate, and they are known to delay retrograde cellular atrophy and apoptosis (Kobayashi et al., 1997; Bregman et al., 1998) and to promote local branching and sprouting (Schnell et al., 1994; Sawai et al., 1996). Likely, convergent signaling by multiple growthpromoting molecules is important in regeneration. Laminin, an extracellular matrix protein, is able to stimulate rapid neurite growth (Kuhn et al., 1995), and we have documented that, in the presence of laminin, neurites can extend directly on myelin substrates (David et al., 1995). Similarly, it has been documented that when the adhesion molecule L1 is expressed ectopically on astrocytes, it can partially overcome their nonpermissive substrate properties (Mohajeri et al., 1996). Therefore, neurons can, under appropriate conditions, grow axons on inhibitory substrates, demonstrating that the balance of positive-to-negative growth cues is a critical determinant for the success or failure of axon regrowth after injury and that multiple signals converge to regulate axon growth.

The Rho signaling pathway has been implicated in both positive and negative signaling events within neurons. Activation of the small regulatory GTPases may be an important link between signaling through integrins, signaling cascades of trophic factors, and regulation of cytoskeletal dynamics (Schlaepfer et al., 1996; Udagawa and McIntyre, 1996; Hall, 1998). Moreover, both MAG and the other myelin-derived growth inhibitory proteins block axon extension by causing growth cone collapse (Bandtlow et al., 
1993; Li et al., 1996). Rho has been implicated in signaling to the growth cone cytoskeleton (Mackay et al., 1996; van Leeuwen et al., 1997) and in regulating growth cone collapse and the retraction of neurites (Jalink et al., 1994; Tigyi et al., 1996b; Katoh et al., 1998). These studies prompted us to first examine in PC12 cells and cultures of primary neurons the role of Rho in growth inhibition by MAG and by myelin. To investigate this possibility, we have made use of the $\mathrm{C} 3$ enzyme from Clostridium botulinum that selectively ADP-ribosylates Rho in its effector domain without affecting Rac and Cdc42, two other members of the Rho family (Rubin et al., 1988; Udagawa and McIntyre, 1996). Furthermore, we demonstrate axons regenerate in vivo after treatment of injured optic nerve with $\mathrm{C} 3$ to inactivate Rho.

\section{MATERIALS AND METHODS}

Preparation of growth substrates and recombinant proteins. Poly-L-lysine was obtained from Sigma (St. Louis, MO). Laminin was prepared from Engelbreth-Holm-Swarm tumors (Paulsson and Lindblom, 1994). Myelin was made from bovine brain corpus callosum, and native MAG was purified from myelin after extraction in $1 \%$ octylglucoside and separation by ion exchange chromatography (McKerracher et al., 1994). This preparation of native MAG has some additional proteins, including tenascin (Z. C. Xiao, P. Braun, S. David, and L. McKerracher, unpublished observations). Recombinant MAG (rMAG) was made in baculovirusinfected Spodoptera frugiperda (SF) cells as described previously (Shibata et al., 1998), except that the SF9 cells were transferred to serum-free conditions before collecting the culture supernatant. Test substrates were prepared as uniform substrates in 96-well plates or eight-chamber LabTek slides (Nunc, Naperville, IL.). For all substrates, plates were precoated with poly-L-lysine $(100 \mu \mathrm{g} / \mathrm{ml})$ for $3 \mathrm{hr}$ at $37^{\circ} \mathrm{C}$ and then washed and dried. MAG or myelin substrates were prepared in 96 -well plates by drying down $4-8 \mu \mathrm{g}$ of protein overnight. The plasmid pGEX2T-C3 coding for the glutathione $S$-transferase (GST)-C3 fusion protein was obtained from N. Lamarche (McGill University, Montréal, Québec, Canada), and recombinant C3 was purified as described previously (Ridley and Hall, 1992). Briefly, the GST fusion protein was cleaved by thrombin, and thrombin was removed by incubation with $100 \mu$ l of $p$-aminobenzamidine agarose beads (Sigma). The C3 solution was dialyzed against PBS and sterilized with a $0.22 \mu \mathrm{m}$ filter. The C3 concentration was evaluated by protein assay (DC assay; Bio-Rad, Missassauga, Ontario, Canada), and C3 purity was controlled by SDS-PAGE analysis.

Cell culture. We used PC12 cells obtained from three different sources: the American Type Culture Collection, Dr. Phil Barker (Montréal Neurological Institute, McGill University), and Gabor Tigyi (University of Tennessee, Memphis, TN). We found that all lines were inhibited by both myelin and MAG in contrast to a different PC12 line tested under different experimental conditions (Rubin et al., 1995). PC12 cells were grown in DMEM with $10 \%$ horse serum and $5 \%$ fetal bovine serum. Human wild-type RhoA was obtained from Dr. A. Hall (University College, London, UK), and a dominant negative mutation was generated by replacing Thr19 for Asn (N19TRhoA). This mutated RhoA was cloned into the $B g l l I I$ site of the pEXV mammalian expression plasmid, and N19TRhoA or mock (empty vector)-transfected PC12 cells were selected, cloned, and characterized (Sebok et al., 1999). To identify Rho proteins expressed by PC12 cells, cell lysates were prepared and ribosylated with $\mathrm{C} 3$ and $\left[{ }^{32} \mathrm{P}\right] \mathrm{NAD}+$ as described previously (Dillon and Feig, 1995), and the different Rho proteins were detected by two-dimensional gel electrophoresis and identified as described previously (Santos et al., 1997). For C3 experiments, PC12 cells were washed once with scraping buffer (in mM: $114 \mathrm{KCl}, 15 \mathrm{NaCl}, 5.5 \mathrm{MgCl}_{2}$, and 10 Tris- $\mathrm{HCl}$ ) and then scraped with a rubber policeman into $0.5 \mathrm{ml}$ of scraping buffer in the presence or absence of $40 \mu \mathrm{g} / \mathrm{ml} \mathrm{C} 3$ transferase. The cells were pelleted and resuspended in $2 \mathrm{ml}$ of DMEM, $1 \% \mathrm{FBS}$, and $50 \mathrm{ng} / \mathrm{ml}$ nerve growth factor before plating. Quantitative analysis of neurite outgrowth was with the aid of Northern Eclipse software (Empix Imaging, Mississauga, Ontario, Canada). Data analysis and statistics were with Microsoft (Seattle, WA) Excel. At least four experiments, each done in duplicate, were analyzed for each treatment. Experiments on MAG substrates were analyzed by phase-contrast microscopy. Because myelin is phase dense, experiments with myelin substrates were by fluorescent microscopy with DiI-labeled cells (McKerracher et al., 1994). For each well, four images were collected with a $20 \times$ objective using a Zeiss (Oberkochen, Ger- many) Axiovert microscope. For each image, the number of cells with and without neurites was counted, and the length of the longest neurite per cell was determined.

To culture retinal neurons, retinas were removed from postnatal day 1 (P1)-P5 rat pups, and the cells were dissociated with $12.5 \mathrm{U} / \mathrm{ml}$ papain in HBSS, $0.2 \mathrm{mg} / \mathrm{ml}$ DL-cysteine, and $20 \mu \mathrm{g} / \mathrm{ml}$ bovine serum albumin. The dissociated cells were washed and then triturated with $\mathrm{C} 3$ or buffer in culture media. Cells were plated on test substrates in the presence of 50 $\mu \mathrm{g} / \mathrm{ml}$ BDNF in DMEM with $10 \% \mathrm{FBS}$, vitamins, and penicillin-streptomycin in the presence or absence of 25 or $50 \mu \mathrm{g} / \mathrm{ml} \mathrm{C} 3$ transferase. Quantitative analysis was done with cells treated with $25 \mu \mathrm{g} / \mathrm{ml} \mathrm{C}$. Neurons were visualized by fluorescent microscopy with anti- $\beta$ III tubulin antibody, which detects growing retinal ganglion cells (RGCs) (Fournier and McKerracher, 1997).

To examine the efficiency of C3 scrape loading, PC12 cells or retinal neurons were treated with $\mathrm{C} 3$ or scrape-loading buffer as described above. After $2 \mathrm{~d}$ in culture, cells were washed with PBS and lysed in 50 mм Tris-HCl, pH 7.8, 150 mM NaCl, 2 mm EDTA, 1\% Triton X-100, 1 $\mathrm{mM}$ PMSF, $1 \mu \mathrm{g} / \mathrm{ml}$ leupeptin, $1 \mu \mathrm{g} / \mathrm{ml}$ aprotinin, and $1 \mu \mathrm{g} / \mathrm{ml}$ pepstatin. Lysates were cleared by centrifugation, and protein concentrations evaluated by DC assay (Bio-Rad). Ten micrograms of protein was separated on $11 \%$ acrylamide gels and transferred to nitrocellulose, and membranes were blocked with TBS containing $0.1 \%$ Tween 20 and $5 \%$ nonfat milk powder, incubated in blocking buffer with anti-RhoA antibody (Upstate Biotechnology, Lake Placid, NY), and revealed with and HRPbased chemiluminescent kit (Boehringer Mannheim, Laval, Quebec, Canada). Membranes were reprobed with polyclonal antibody against Cdc42 (Upstate Biotechnology) and secondary alkaline phosphataselinked anti-rabbit antibody and revealed with nitroblue tetrazolium chloride-5-bromo-4-chloro-3-indyl-phosphate (NBT-BCIP) (Canadian Life Technology, Burlington, Ontario, Canada).

C3 treatment of crushed optic nerve in adult rats. Rats were anesthetized with $0.6 \mathrm{ml} / \mathrm{kg}$ hypnorm, $2.5 \mathrm{mg} / \mathrm{kg}$ diazepan, and $35 \mathrm{mg} / \mathrm{kg} \mathrm{ketamin}$. To make microcrush lesions, the left optic nerve was exposed by a supraorbital approach, the optic nerve sheath was slit longitudinally, and the optic nerve was lifted out from the sheath and crushed $1 \mathrm{~mm}$ from the globe by constriction with a 10.0 suture held for $60 \mathrm{sec}$ (see Fig. 5a). To verify the lesion was complete, Fluorogold (Flurochrome Inc., Englewood, NJ) was applied bilaterally to the superior colliculus ( $n=3$ animals), and the left (microcrush-lesioned) and right retinas were visualized as whole mounts (Selles-Navarro et al., 1996). Lesions were also examined by anterograde tracing $24 \mathrm{hr}$ after lesion (see below; $n=4$ animals). For C3 treatment and buffer controls, Gelfoam soaked in PBS or $2 \mathrm{mg} / \mathrm{ml} \mathrm{C} 3$ transferase was placed on the nerve at the lesion site. Two 3-mm-long tubes of Elvax (Sefton et al., 1984) loaded with buffer or $20 \mu \mathrm{g}$ of C3 were inserted in the Gelfoam near the nerve for continued slow release of C3 (see Fig. 5a). To anterogradely label RGC axons, $5 \mu$ l of $1 \%$ cholera toxin $\beta$ subunit (CT) (List Biologic, Campbell, CA) was injected into the vitreous, for either $2 \mathrm{~d}$ [dichlorotriazinyl amino fluorescein (DTAF)-labeled] or $3 \mathrm{hr}$ [3,3'-diaminobenzidine tetrahydrochloride (DAB)-labeled]. Two weeks after optic nerve crush, the animals were fixed by perfusion with $4 \%$ paraformaldehyde, and the eye with attached optic nerve was removed and post-fixed in $4 \%$ paraformaldehyde. Optic nerve were treated in one of two ways. (1) Longitudinal $14 \mu \mathrm{m}$ cryostat sections were processed for immunoreactivity to CT with goat anti-CT at 1:12,000 (List Biologic), followed by rabbit anti-goat biotinylated antibody (1:200; Vector Laboratories, Burlingame, CA) and DTAF-streptavidin (1:500; Jackson ImmunoResearch, West Grove, Pa) and viewed with epifluorescence. Some of these sections were further examined for confirmation of the location of the crush and for myelin staining by a Luxol fast blue-cresyl violet procedure. After photomicrographs of the fluorescent images were taken, the coverslips were removed, and the slides were soaked in PBS, passed through 95\% ethanol, and stained in $1 \%$ Luxol fast blue overnight. The slides were rinsed in water, differentiated in $0.005 \%$ lithium carbonate, and then left in $70 \%$ ethanol until the unmyelinated fibers in the retina cleared. The slides were counterstained with $0.05 \%$ cresyl violet, dehydrated, and mounted with Permount. (2) Optic nerves were embedded in $20 \%$ gelatin, further fixed in $4 \%$ paraformaldehyde for $6-8 \mathrm{hr}$, and cryoprotected in $30 \%$ sucrose, and longitudinal $30 \mu \mathrm{m}$ cryostat sections were cut and processed as free-floating sections. The nerves were treated with goat anti-CT as above, incubated with avidin-biotin HRP complex (ABC; Vector Laboratories), and rinsed in $0.1 \mathrm{M}$ potassium phosphate buffer, $\mathrm{pH}$ 7.2. The color reaction was by incubating sections in $0.05 \%$ DAB, $0.01 \%$ cobalt chloride, and $0.01 \%$ nickel sulfate for $5 \mathrm{~min}$ before adding $0.006 \% \mathrm{H}_{2} \mathrm{O}_{2}$ for $3-5 \mathrm{~min}$. 

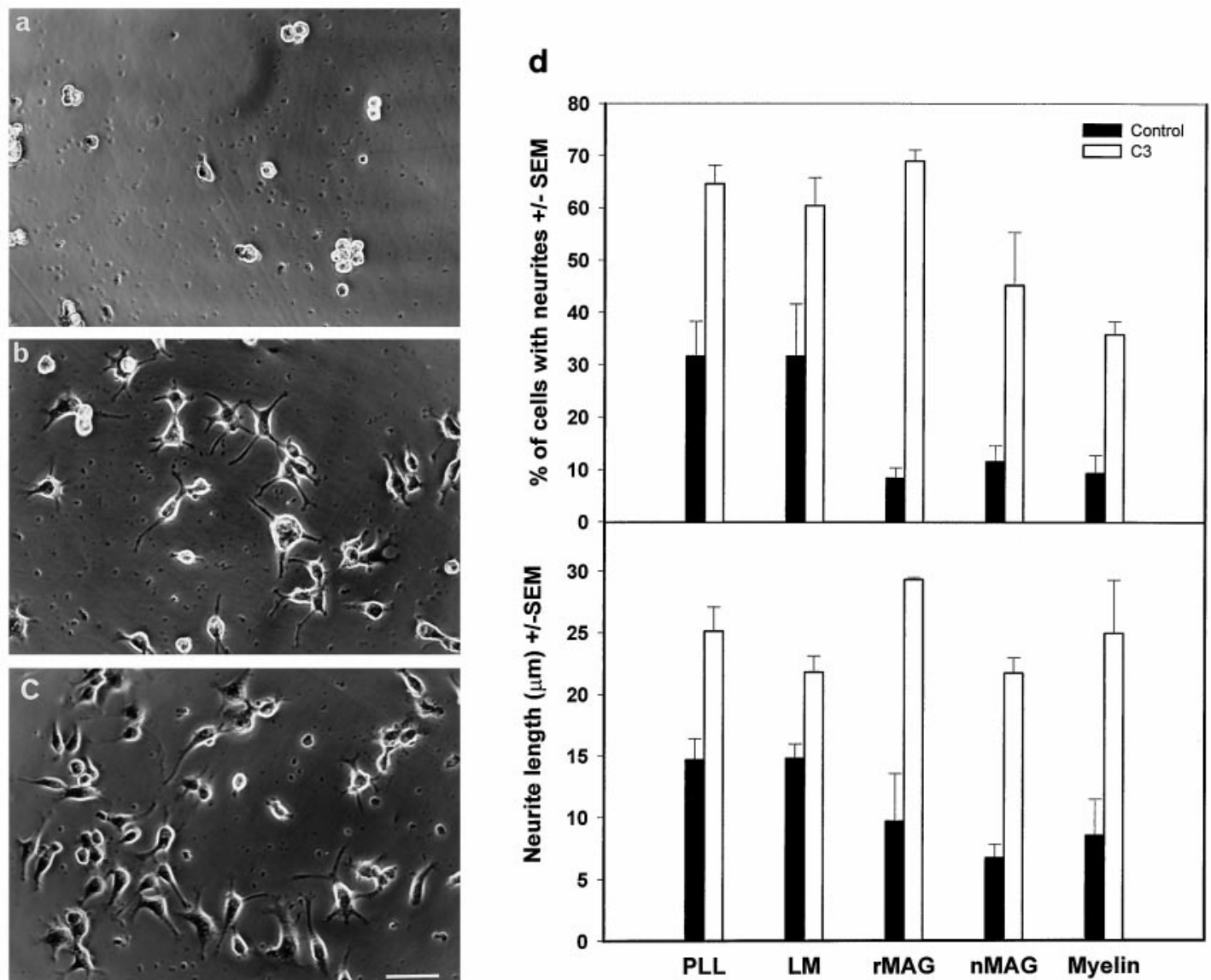

Figure 1. $\mathrm{C} 3$ treatment of PC12 cells plated on inhibitory MAG and myelin substrates. $a-c$, PC12 cells plated on MAG remained rounded and did not extend neurites $(a)$, but cells plated on MAG in the presence of C3 $(b)$ grew neurites. $c$, Poly-L-lysine $(P L L)$ controls. Scale bar, $50 \mu \mathrm{m}$. $d$, Quantitative analysis of neurite growth with C3 treatment (open bars) or in scrape-loaded buffer controls ( filled bars) when PC12 cells were plated on poly-L-lysine, laminin, rMAG, native MAG $(n M A G)$, or myelin. The number of cells that extended neurites after 18-24 hr of treatment was counted (top), and the length of the longest neurite per cell was measured (bottom).

For a quantitative analysis, the numbers of axons per section were counted at distances of 100,250 , and $500 \mu \mathrm{m}$, and at least four sections per animal were analyzed (see Fig. 9).

\section{RESULTS}

\section{Effect of $\mathrm{C} 3$ transferase on PC12 cells}

PC12 cells typically extend neurites in response to NGF, but, when plated on myelin substrates, the cells remain round and do not extend neurites (Rubin et al., 1995). We plated three different lines of PC12 cells on both native and recombinant MAG substrates (Fig. 1). All of the lines of PC12 cells showed reduced cell spreading and remained round without neurites in the presence of NGF. Next, we inactivated Rho in PC12 cells by scrape loading cells with purified recombinant $\mathrm{C} 3$ at $40 \mu \mathrm{g} / \mathrm{ml}$ before plating the cells on the test substrates (Fig. 2). On MAG substrates, in which neurite formation is inhibited, $\mathrm{C} 3$ had a dramatic effect on the ability of cells to extend neurites (Fig. $1 a-c$ ). On control substrates of poly-L-lysine and laminin, treatment with C3 increased both the number of cells with neurites and the length of neurites (Fig. 1d). Moreover, on both MAG and myelin substrates, significantly more cells extended neurites, and neurite length was significantly longer after C3 treatment (Fig. 1d). These results demonstrate that $\mathrm{C} 3$ treatment elicits neurite growth from $\mathrm{PC} 12$ cells plated on growth-inhibitory myelin or MAG substrates.

To ensure that the effect of $\mathrm{C} 3$ treatment resulted from uptake

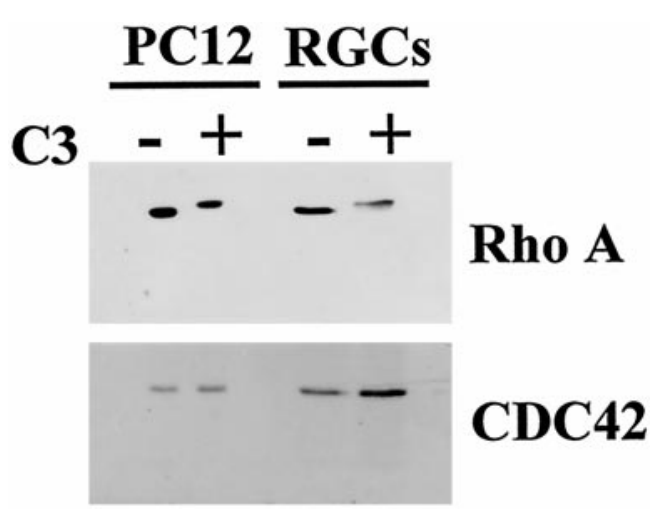

Figure 2. ADP-ribosylation of Rho by $\mathrm{C} 3$ detected in cultured cells. PC12 cells or retinal neurons were cultured in the presence $(+)$ or absence $(-)$ of $\mathrm{C} 3$ for $2 \mathrm{~d}$. The cells were lysed, and $10 \mu \mathrm{g}$ of protein from each sample was separated on a $11 \%$ acrylamide gel. The proteins were transferred to nitrocellulose, probed with mouse anti-RhoA antibody and anti-mouse-HRP antibody, and revealed by a chemiluminescent reaction (top). The membranes were then reprobed with rabbit anti-Cdc42 and anti-rabbit alkaline phosphatase and revealed with NTB/BCIP color reaction. Treatment of cells with $\mathrm{C} 3$ results in an ADP-ribosylationinduced decrease in the mobility of RhoA. The mobility of Cdc42 does not change with $\mathrm{C} 3$ treatment. 

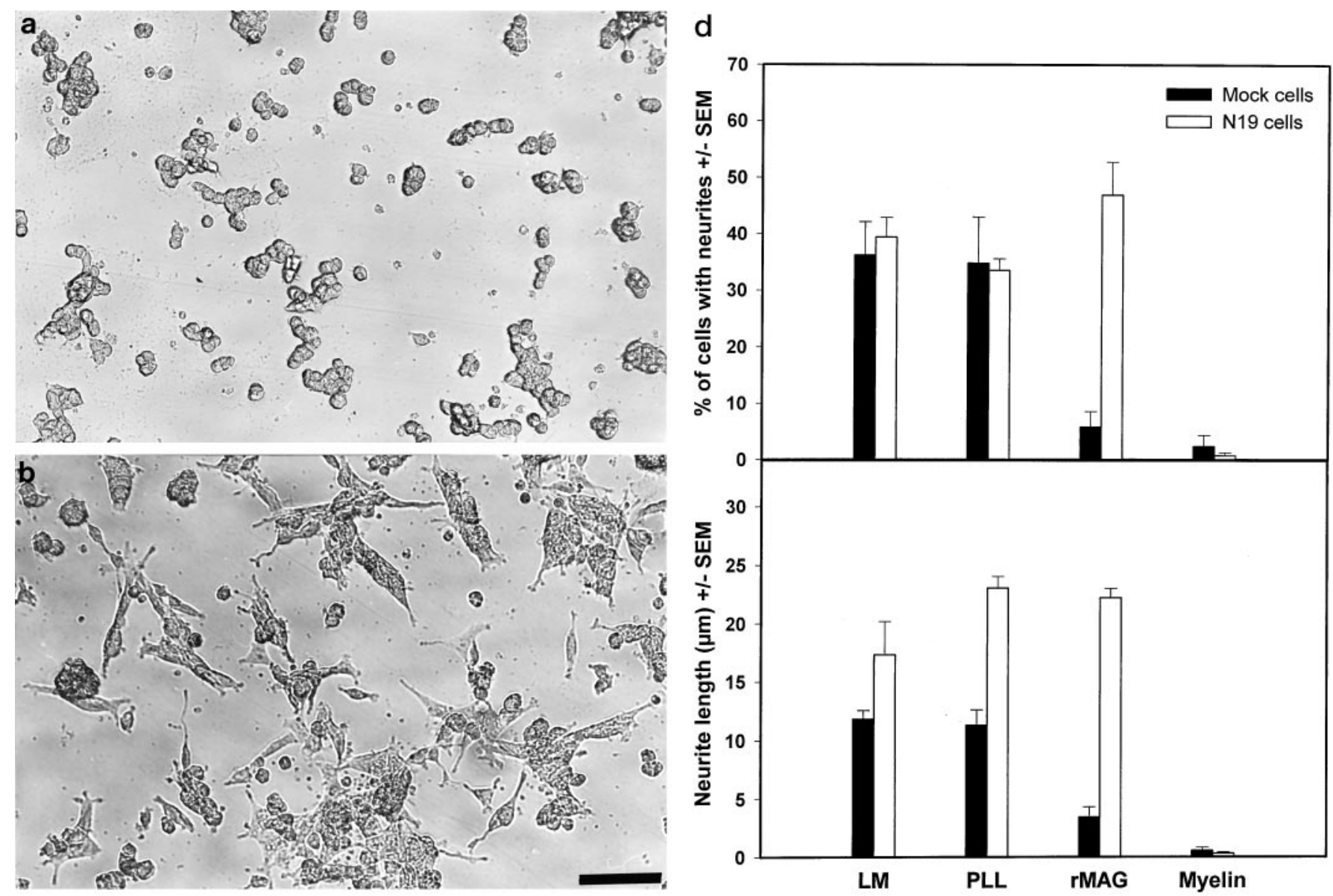

C

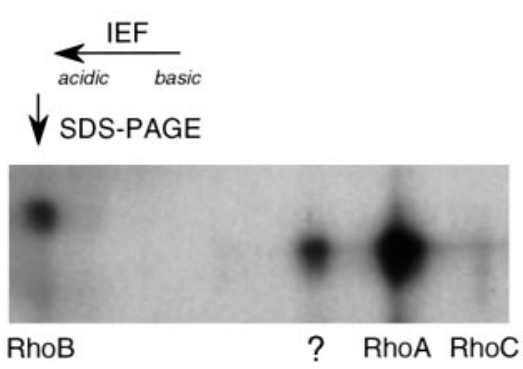

Figure 3. PC12 cells transfected with dominant negative RhoA extend neurites on MAG substrates. $a, b$, Mock-transfected cells $(a)$ do not extend neurites on MAG, whereas N19TRhoA cells $(b)$ were able to spread and extend neurites on MAG substrates. Scale bar, $80 \mu \mathrm{m}$. $c$, ADP-ribosylation of Rho proteins in PC12 cell membranes reveal that PC12 cells express RhoA, RhoB, and RhoC. $d$, Quantitative comparison of the percentage of mock-transfected (open bars) or N19TRhoA ( filled bars) cells that grow neurites on different test substrates. The number of cells that grow neurites (top) was significantly different from N19TRhoA cells plated on MAG. $c$, ADP-ribosylation of Rho proteins in PC12 cell membranes. Isolation of crude plasma membrane, ADP-ribosylation, and two-dimensional gel electrophoresis was performed as described previously (Santos et al., 1997). RhoA, RhoB, RhoC, and an unidentified protein are ADP-ribosylated. of C3 into the cells, we examined by Western blot the electrophoretic mobility of Rho in PC12 cells treated with C3 or with scrape-loading buffer as a control (Fig. 2). It has previously been shown that ADP-ribosylation of Rho results in decreased mobility of Rho on SDS-acrylamide gels (Narito and Narumiya, 1995). Western blots of cell lysates with anti-RhoA antibody revealed an increase in the apparent molecular weight of RhoA in cells treated with $\mathrm{C} 3$. As a control for the specificity of the effect, we probed the same blots for another small GTPase of the Rho family, Cdc42. Cdc42 did not show any change in mobility after treatment with $\mathrm{C} 3$ (Fig. 2), demonstrating the specificity of $\mathrm{C} 3$ treatment under our experimental conditions.

\section{Growth of dominant negative Rho-transfected cells on MAG substrates}

PC12 cells transfected with dominant negative RhoA (N19TRhoA) show enhanced neurite extension after exposure to NGF (Sebok et al., 1999). The N19TRhoA cells and the mocktransfected cells were compared for their ability to extend neu- rites on different inhibitory substrates (Fig. 3a,b). N19TRhoA cells plated on rMAG substrates were able to extend neurites, and the neurites were significantly longer than those of the mocktransfected cells plated on rMAG (Fig. $3 d$ ). On myelin substrates, the N19TRhoA cells were unable to extend neurites (Fig. 3d). To examine whether other members of the Rho family are also present in PC12 cells, we examined by ADP-ribosylation of membrane proteins the Rho proteins expressed in PC12 cells (Fig. 3c). These experiments revealed that PC12 cells express RhoA, RhoB, RhoC, as reported for brain (Dillon and Feig, 1995). The inability of the N19TRhoA cells to extend neurites on myelin is consistent with the report of incomplete inhibition of Rho activity by dominant negative mutations (Qiu et al., 1995). Inactivation of all of the Rho proteins or of a threshold amount of RhoA may be necessary for neurites to extend on myelin substrates.

\section{Effect of C3 on primary cells}

To test the involvement of Rho in the response of primary neurons to MAG and to myelin substrates, we purified retinal 

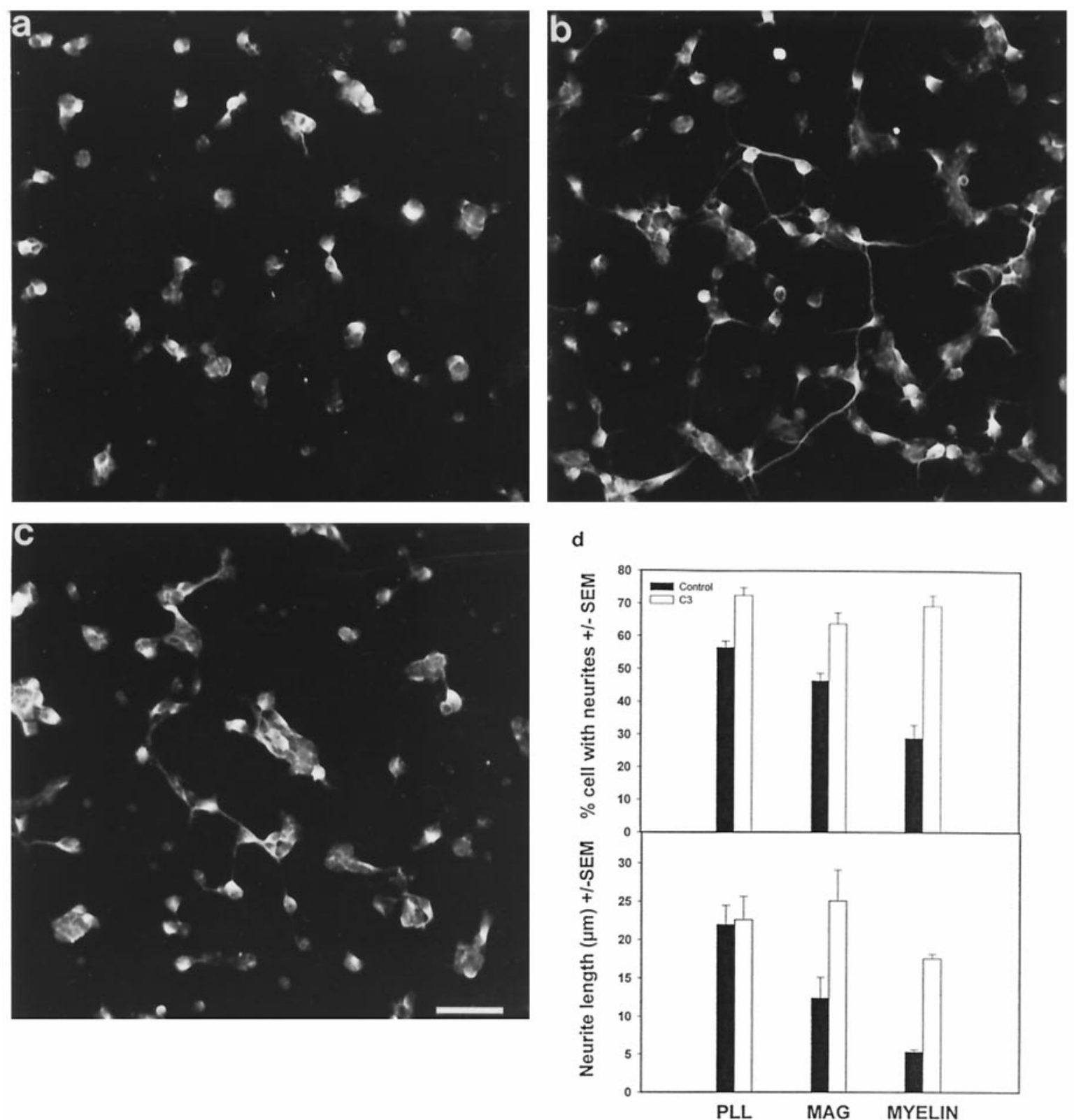

Figure 4. Treatment of retinal neurons with $\mathrm{C} 3$ stimulates neurite growth on MAG substrates. On native MAG substrates, neurite growth is inhibited $(a)$, but after $\mathrm{C} 3$ treatment, retinal neurons plated on native MAG substrates extend neurites $(b)$. Growth of neurites from retinal neurons plated on poly-L-lysine $(c)$. Scale bar, $50 \mu \mathrm{m}$. $d$, Quantitative analysis of neurite growth of retinal neurons on poly-L-lysine, MAG, and myelin substrates, as described in the legend of Figure 1. Significantly more cells extended longer neurites on MAG and myelin substrates with C3 treatment than with buffer-treated controls. Scale bar, $50 \mu \mathrm{m}$.

neurons and treated them with C3. Neurite outgrowth from these cells was inhibited by MAG (Fig. 4a) and myelin (Fig. 4d). Treatment of retinal neurons with C3 allowed neurite extension on the growth-inhibitory MAG substrates to an extent similar to that observed on control substrates (Fig. 4b,c). A quantitative analysis revealed that $\mathrm{C} 3$ treatment of retinal neurons plated on MAG or myelin substrates had significantly longer neurites, and significantly more cells extended neurites (Fig. 4d). Also, we documented that, in retinal neurons treated with $\mathrm{C} 3$, a shift in the mobility of Rho, but not Cdc42, was detected (Fig. 2). These experiments demonstrate that inactivation of Rho by ADP- ribosylation allows retinal neurons to extend neurites on growthinhibitory substrates.

\section{Effects of $\mathrm{C} 3$ on retinal ganglion cell axon growth in vivo}

It is known from studies with retrograde tracers that damaged axons can take up externally applied substances. Therefore, we explored the possibility that transected axons treated with C3 would foster regeneration in vivo. The RGC response to injury has been well documented (Vidal-Sanz et al., 1987; Villegas-Perez et al., 1988; Ajemain, David, 1994; Berkelaar et al., 1994; Berry et 


\section{A. Crush}

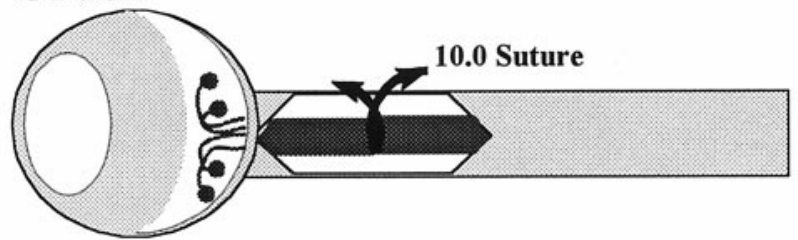

B. Treatment with C3 or PBS

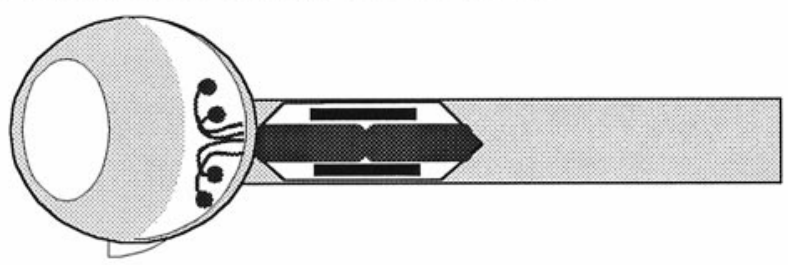

C. Anterograde Labeling

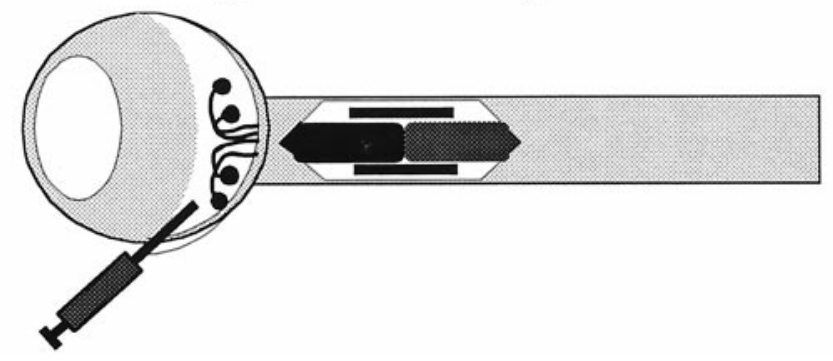

Figure 5. Illustration of methods used to study the effect of $\mathrm{C} 3$ on injured RGC axons. $a$, The optic nerve was removed from the sheath before crushing with 10.0 sutures. $b, \mathrm{C} 3$ was applied in Gelfoam and Elvax tubes immediately after crushing the optic nerve. $c$, Retinal ganglion cell axons were detected by anterograde labeling with $\mathrm{CT}$.

al., 1996), and we examined regeneration of RGC axons in the optic nerve 2 weeks after injury. Recently, it has been shown that microlesions in the CNS reduce the extent of the glial scar to allow axonal growth from transplanted adult neurons into CNS white matter (Davies et al., 1997). To reduce possible effects of the glial scar, we made microcrush lesions of optic nerve to axotomize RGC axons (Fig. 5). To verify that this method completely axotomized RGC axons, we applied the retrograde tracer Fluorogold to the superior colliculus at the time of microcrush lesion and examined retinal whole mounts for the presence of labeled cells. After microcrush lesion $(n=3)$, the RGCs failed to become labeled, indicating that the lesion was complete (Fig. $6 a$ ). With unlesioned optic nerves $(n=3)$, the RGC population was normally labeled (Fig. 6b). In addition, anterograde labeling (Fig. $5 d$ ) of microcrush-lesioned RGC axons $24 \mathrm{hr}$ after injury verified that RGC axons were effectively axotomized ( $n=4$ animals; data not shown).

To apply C3 to microcrush-lesioned optic nerves, C3 in Gelfoam was wrapped around the site of crush, and two Elvax tubes, each loaded with $\mathrm{C} 3$, were positioned for sustained slow release (Fig. 5). For these experiments, 16 animals were treated with C3, 10 animals were treated with Gelfoam and Elvax tubes with buffer as controls, and four animals received microcrush lesion only. All animals were examined 2 weeks after surgery. Regenerating axons were visualized by anterograde labeling with CT injected into the eye, and longitudinal cryostat sections of the optic nerves were examined for cholera toxin immunoreactivity. In all 10 of the buffer-treated animals, most anterogradely labeled axons stopped
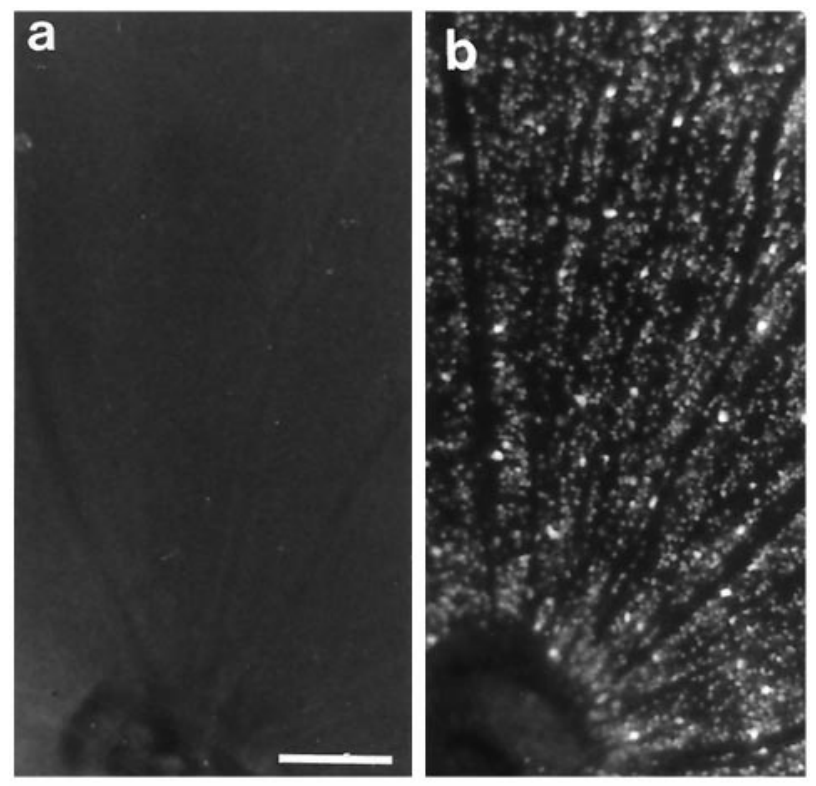

Figure 6. Retinal whole mounts visualized after the application of Fluorogold to the tectum demonstrate the microcrush lesion is a complete lesion. $a$, Retinas are not labeled by Fluorogold applied to the tectum after a microcrush lesion. $b$, A control retina to show the normal pattern of retrograde labeling with Fluorogold.

abruptly at the crush site (Figs. $7 a, 8 c$ ), although a few axons did extend past the crush (Fig. $8 c$, arrows). In these controls, axon extension past the crush site was typically restricted to the edge of the optic nerve. After treatment with C3, large numbers of axons extended through the site of the crush, both along the edge (Fig. $8 c$ ) and in the middle of the optic nerve (Figs. 7b,c, 8d). This observation of regenerating axons throughout the thickness of the optic nerve was confirmed by examining serial sections (Fig. 7). After C3 treatment, many of the axons that extended past the lesion site showed a twisted path of growth, supporting their identification as regenerating axons (Fig. 8e). Counterstaining of the fluorescently labeled sections with Luxol fast blue-cresyl violet confirmed that the fluorescently labeled axons extended past the crush and into regions of the nerve that remained myelinated (Fig. 8b). To examine quantitatively the differences between $\mathrm{C} 3$ and buffer-treated animals, we counted the number of axons in each section at distances of 100, 250, and $500 \mu \mathrm{m}$ past the lesion site in all of the animals examined with the two immunolabeling methods (Fig. 9a). Significantly more axons extended past the lesion in the C3-treated animals than in the microcrush lesion or buffer-treated controls at distances of 100 and $250 \mu \mathrm{m}$ (Fig. 9b). Therefore, C3 applied to injured RGC axons can enter axotomized axons and promote robust but shortlived axon regeneration in the environment of the optic nerve.

\section{DISCUSSION}

Here, we report that the small GTP binding protein Rho is a key intermediate in the neuronal response to neurite growthinhibitory signals. Although it is known that treatment of neurons with C3 to inactivate Rho can stimulate axon outgrowth of cells plated on poly-L-lysine or laminin (Nishiki et al., 1990; Jin and Strittmatter, 1997; Kozma et al., 1997), we demonstrate here that treatment with $\mathrm{C} 3$ can also overcome growth inhibition by inhibitory substrates. Treatment of cultured PC12 cells and retinal neurons with $\mathrm{C} 3$ enzyme to inactivate Rho allowed neurites to 


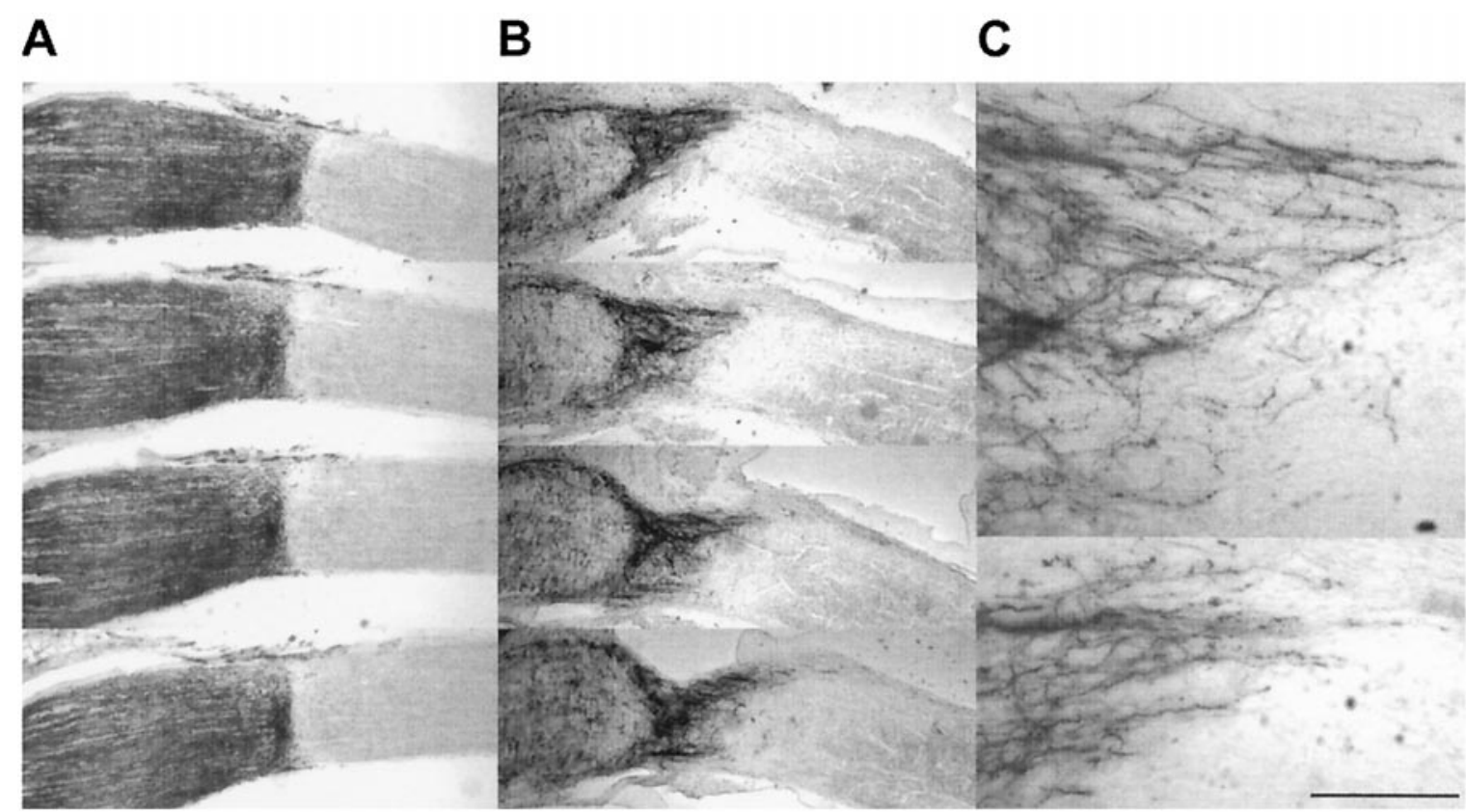

Figure 7. Anterogradely labeled RGC axons detected past the crush in longitudinal sections of C3-treated optic nerve. $a$, A series of four sections through one optic nerve to show that most axons do not extend past a microcrush lesion without $\mathrm{C} 3$ treatment. $b$, A series of four sections though a C3-treated optic nerve to show that many axons extend past the lesion throughout the thickness of the optic nerve. $c$, Higher magnification view of the third and first section shown in $b$. Scale bar: $a, b, 500 \mu \mathrm{m} ; c, 100 \mu \mathrm{m}$.

extend directly on inhibitory substrates of MAG or myelin. Also, PC12 cells transfected with dominant negative RhoA extended neurites on MAG substrates. Therefore, the Rho signaling pathway is likely to play a key role in the integration of both permissive and inhibitory substrate cues in axon growth and regeneration.

\section{Regulation of neurite growth by Rho family members}

There is now good evidence that members of the Rho family regulate axon outgrowth in development. Both activating and null mutations in Rac block the extension of axons in Drosophila (Luo et al., 1994). Activating mutations of Rho disrupt axonal pathfinding in Caenorhabditis elegans, implicating Rho in coupling guidance cues to process outgrowth (Zipkin et al., 1997). Recently, it has been shown that the guidance molecule collapsin acts through a Rac-dependent mechanism (Jin and Strittmatter, 1997). In transgenic mice that express constitutively active Rac in Purkinje cells, there are alterations in the development of axon terminals and dendritic arborizations (Luo et al., 1996). The introduction of mutated Rac, Rho, or Cdc42 into cortical neurons affects dendritic morphology (Threadgill et al., 1997). Immunocytochemical observations of DRG neurons indicate that Rho protein is concentrated in growth cones (Renaudin et al., 1998). Therefore, members of the Rho family regulate axon and dendrite growth in development.

In PC12 cells, dominant negative Rac disrupts neurite outgrowth in response to NGF (Hutchens et al., 1997; Daniels et al., 1998), whereas treatment of PC12 cells with lysophosphatidic acid, a mitogenic phospholipid that activates Rho, or treatment with constitutively active Rho causes neurite retraction (Tigyi et al., 1996b; Kozma et al., 1997). Rapid neurite growth consistently follows treatment with C3 enzyme to inactivate all Rho family members in PC12 cells and primary neurons (Nishiki, 1990, Jalink et al., 1994; Tigyi et al., 1996b; Jin and Strittmatter, 1997;
Kozma et al., 1997). We report here that C3 inactivation of Rho can promote neurite growth of PC12 cells and retinal neurons on MAG and myelin. A recent study reports that both active RhoA and active Rac protect chick motor neurons from growth cone collapse by myelin (Kuhn et al., 1999), but dominant negative Rho and C3 were not tested to permit a direct comparison with our results. The difference between our findings could relate to differences in neuronal cell type. Also, it is possible that different Rho isoforms (i.e., RhoA, B, and C) contribute differently to regulating growth, as found for Rac. Activated $\mathrm{rRac} 1 \mathrm{~B}$ expressed in retinal neurons stimulates neurite growth, whereas activation of Rac1A did not (Albertinazzi et al., 1998). We found that dominant negative RhoA expressed in PC12 cells promoted neurite growth on MAG but not on myelin, perhaps because Rho inhibition by dominant negative constructs can be low (Qiu et al., 1995). We and others (Jin and Strittmatter, 1997) have observed robust neurite growth on myelin substrates when neurons are treated with $\mathrm{C} 3$. We suggest that inactivation of the multiple forms of Rho by treatment with $\mathrm{C} 3$ is the most effective way to overcome growth inhibition by myelin.

In non-neuronal cells, a complementary hierarchy of signaling between Rho, Rac, and Cdc42 has been proposed (Nobes and Hall, 1995). In contrast, Rac and Rho may have opposite effects on neurite growth (Kozma et al., 1997; van Leeuwen et al., 1997): inactivation of Rho stimulates rapid neurite outgrowth (Nishiki et al., 1990; Jalink et al., 1994; van Leeuwen et al., 1997; Katoh et al., 1998), whereas activation of Rac stimulates neurite extension (Kozma et al., 1997; van Leeuwen et al., 1997; Daniels et al., 1998; Albertinazzi et al., 1998). Rho and Rac may have additive effects on growth cone morphology, with activated Rho and inactive Rac cooperating to give a spread growth cone morphology, with lower rates of growth (Jin and Strittmatter, 1997). Kuhn et al. (1999) found that activation of Rho prevented growth cone collapse by 

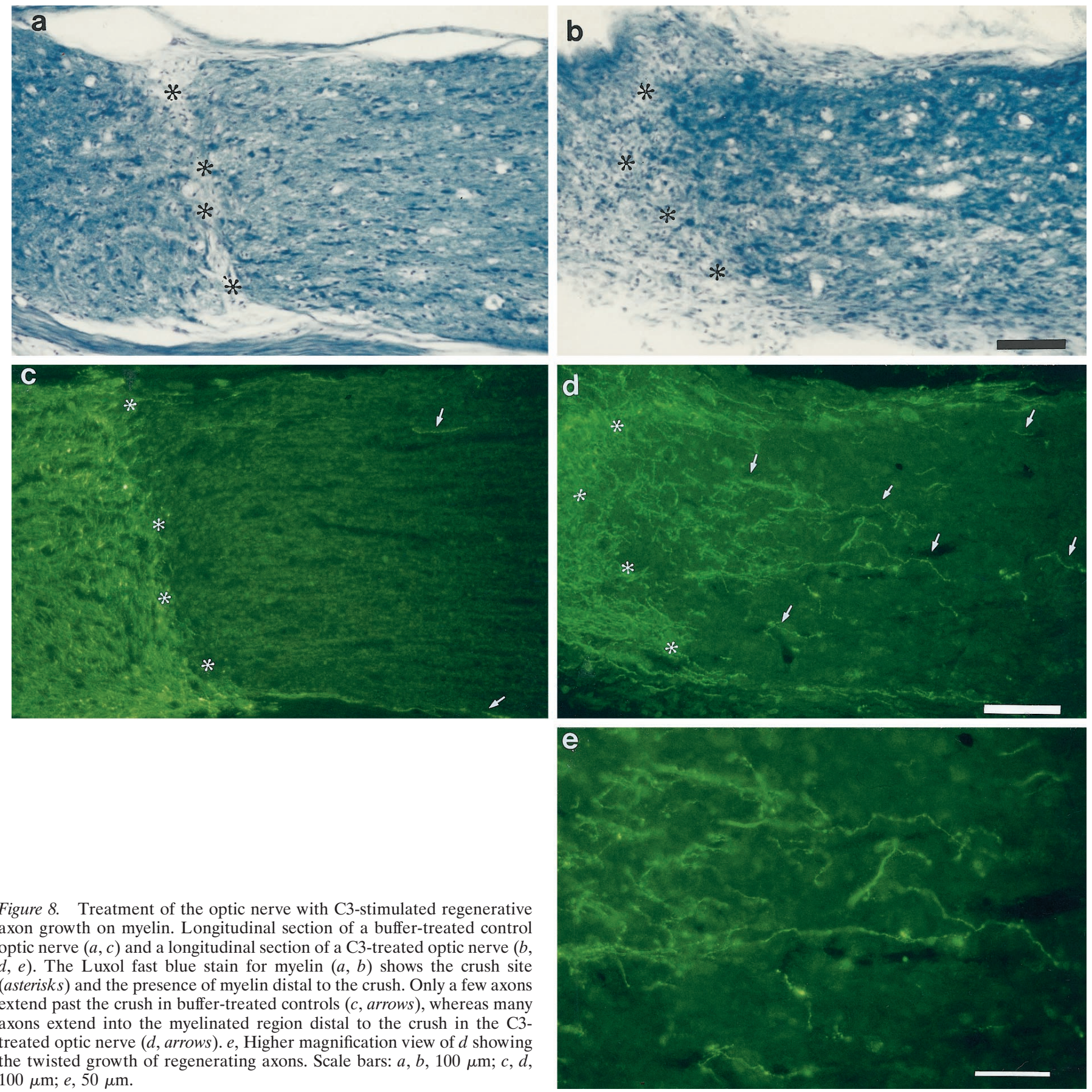

Figure 8. Treatment of the optic nerve with $\mathrm{C} 3$-stimulated regenerative axon growth on myelin. Longitudinal section of a buffer-treated control optic nerve $(a, c)$ and a longitudinal section of a C3-treated optic nerve $(b$, $d, e)$. The Luxol fast blue stain for myelin $(a, b)$ shows the crush site (asterisks) and the presence of myelin distal to the crush. Only a few axons extend past the crush in buffer-treated controls (c,arrows), whereas many axons extend into the myelinated region distal to the crush in the C3treated optic nerve $(d$, arrows). $e$, Higher magnification view of $d$ showing the twisted growth of regenerating axons. Scale bars: $a, b, 100 \mu \mathrm{m} ; c, d$, $100 \mu \mathrm{m} ; e, 50 \mu \mathrm{m}$.

myelin, but growth cone morphology is not always predictive of the growth state. Rapid neurite elongation in the presence of C3 occurs with a collapsed growth cone morphology (Jin and Strittmatter, 1997), and in vivo, rapidly extending axons are bulletshaped (Mason and Wang, 1997). Possibly, the prevention of myelin-derived growth cone collapse by activated Rho (Kuhn et al., 1999) reflects the cooperative affects of Rac and Rho on growth cone morphology.

Recently, it was found that priming cells with neurotrophins increases cAMP levels to block the inhibitory response to MAG (Cai et al., 1999). We note that, under our experimental conditions with retinal ganglion cells, the neurons were not primed before treatment with C3 to inactivate Rho. However, our data that suggest the Rho signaling pathway is a key target for regulating growth cone motility is relevant to the finding that cyclic nucleotides regulate growth cone responses to inhibitory proteins. Growth cone repulsion by MAG can be converted into attraction by elevation of intracellular cAMP levels to activate protein kinase A (PKA) (Song et al., 1998). Experiments with non-neuronal cells have implicated cAMP in the regulation of Rho because elevation of cAMP and activation of PKA inhibit Rho activation (Lang et al., 1996; Laudanna et al., 1996; Dong et al., 1998). Moreover, PKA directly phosphorylates Rho, and this phosphorylation decreases the ability of Rho kinase to interact 


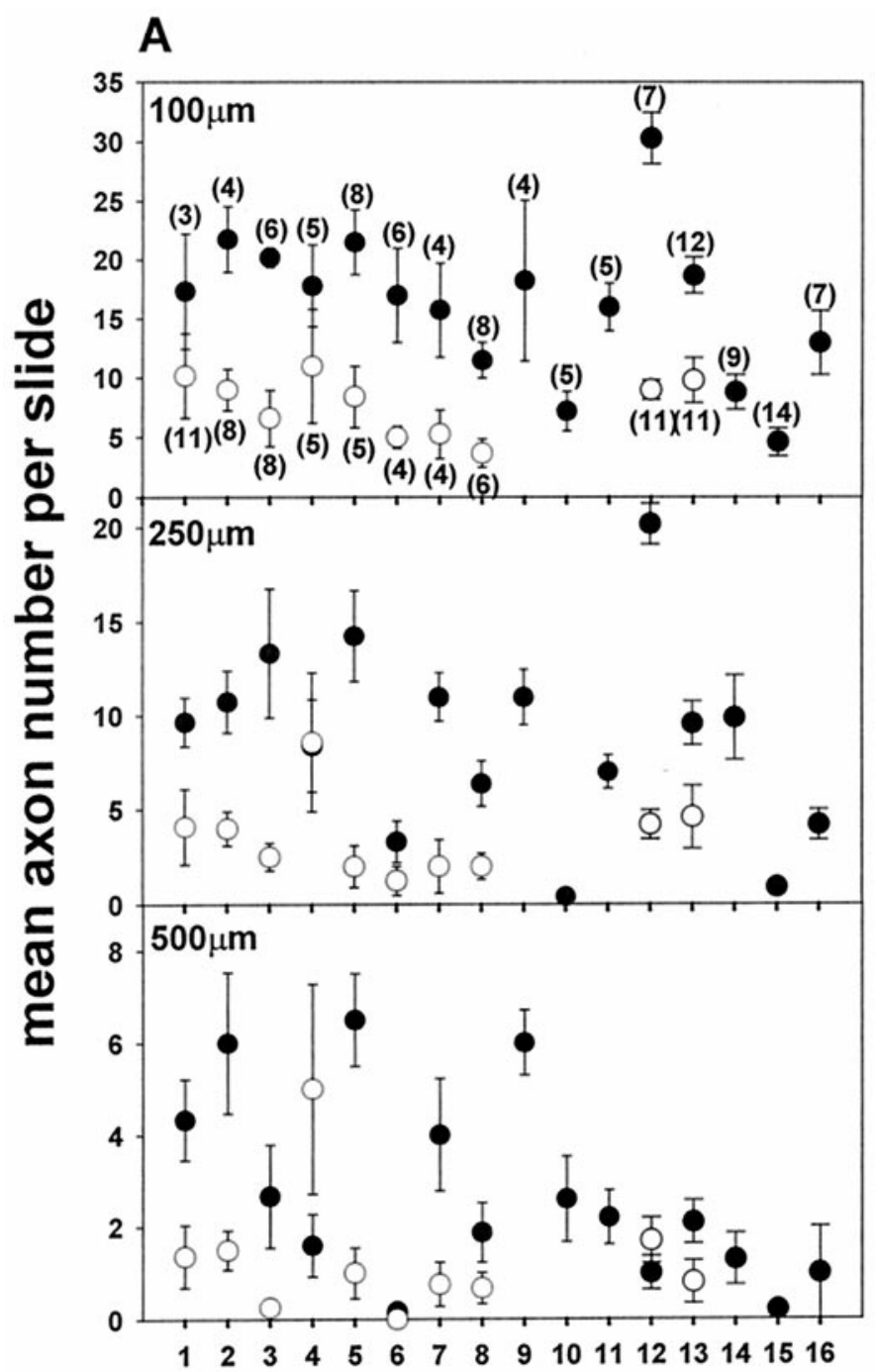

Animal number
B

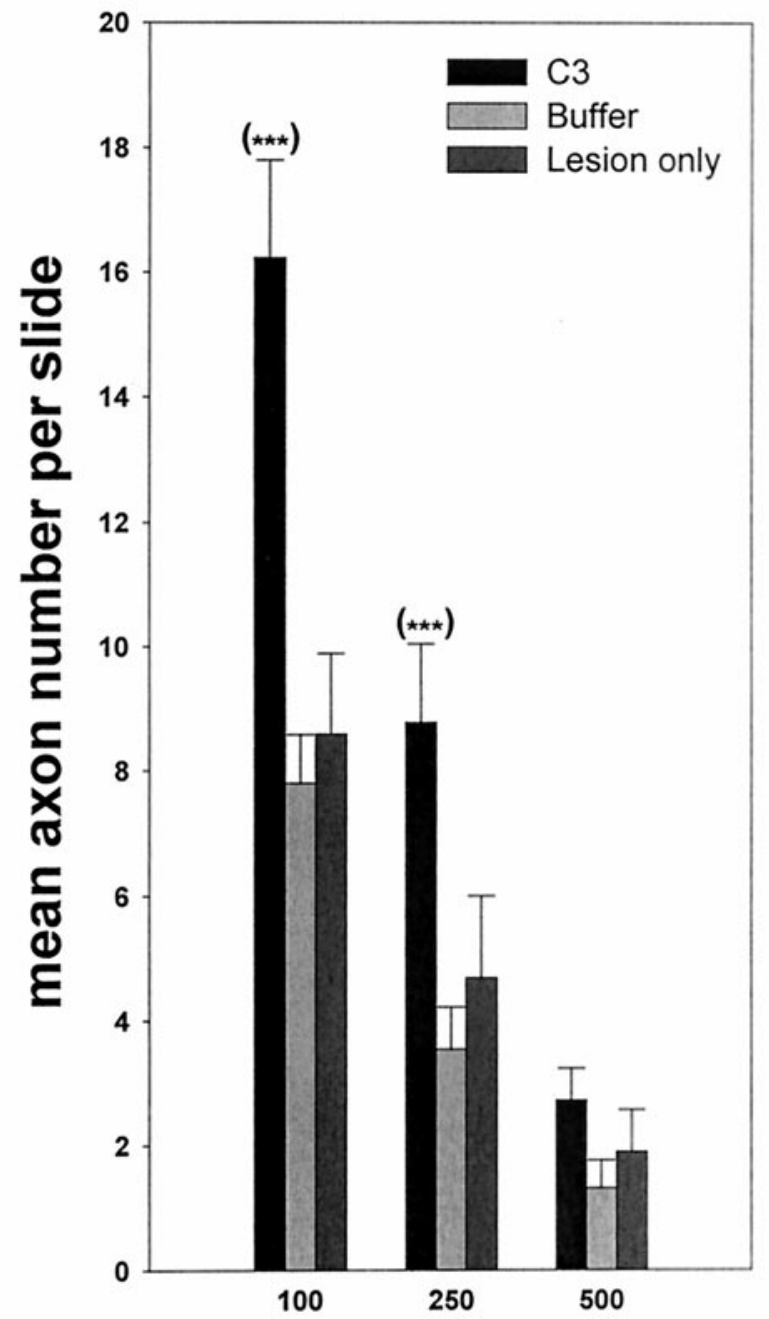

Distance of axonal growth $(\mu \mathrm{m})$

Figure 9. Average axon growth in sections of optic nerves from individual animals. $A$, Quantitative analysis of the average number of RGC axons per section measured at 100, 250, and $500 \mu \mathrm{m}$ for C3-treated $(\bullet)$ and buffer-treated $(\bigcirc)$ animals. Each point represents data from one animal, with the number of sections analyzed for each animal shown in parentheses. Animals 1-11 were examined by fluorescent microscopy (DTAF) and animals $12-19$ by an HRP-DAB reaction. $B$, Pooled results for the three groups of animals: C3-treated, buffer-treated controls, and microcrush lesion alone. Average axon growth after $\mathrm{C} 3$ treatment was significantly greater than buffer control or lesion alone at 100 and $250 \mu \mathrm{m}$.

with activated Rho (Lang et al., 1996; Dong et al., 1998). In PKA-deficient PC12 cells, elevation of cAMP fails to protect from the activation of Rho by lysophosphotydic acid (Tigyi et al., 1996a). It is likely, therefore, that PKA-dependent regulation of Rho occurs in growth cones as well.

Not all of the myelin-derived inhibitory molecules are known to date, and less is known about the neuronal receptors for growth inhibitory molecules. Several different MAG binding partners have been identified (Yang et al., 1996; Collins et al., 1997), and specific neuronal receptors to myelin inhibitors are likely to exist. Targeting intracellular signaling mechanisms converging to Rho rather than individual receptors may be the most practical way to overcome growth inhibition in vivo. The advantage of inactivating Rho to stimulate regeneration is that axons can regenerate directly on the native terrain of the CNS and thus may be more likely to find their natural targets.

\section{The response of adult rat retinal ganglion cells to axonal transection}

Remarkably, we observed that RGC axons crossed the lesion site to enter the distal optic nerve after treatment of injured optic nerve with $\mathrm{C} 3$. The striking feature of our results was the large number of axons that crossed the lesion into the distal white matter compared with buffer-treated controls or after microcrush lesion alone. Studies of RGC regeneration after treatment with IN-1 antibody to block myelin inhibitors have demonstrated that RGC axons do not regenerate long distances compared with axons in the spinal cord (Bartsch et al., 1995). One further barrier to axonal regeneration is the cell death by apoptosis that follows axonal injury. This has been thoroughly characterized for RGCs in which the type of injury (cut or crush) and distance of the lesion from the retina influence the extent of cell death (VillegasPerez et al., 1988, 1993; Berkelaar et al., 1994). Treatment of the 
optic nerve with C3 is unlikely to prevent the apoptosis that follows injury. The number of axons that we observed to regenerate likely represents $<1 \%$ of the normal RGC population, but only $5-18 \%$ of retinal ganglion cells are expected to be alive 2 weeks after intraorbital lesion (Villegas-Perez et al., 1988; Berkelaar et al., 1994). When RGC do regenerate their axons after grafting of a peripheral nerve, which also provides some trophic support (Villegas-Perez et al., 1988), an average of only $3 \%$ of RGC axons regrow (Vidal-Sanz et al., 1987).

Our observations of microcrush-lesioned optic nerves after treatment with $\mathrm{C} 3$ provide the first evidence that treatment of injured white matter tracts with $\mathrm{C} 3$ can help foster regeneration after injury. Whereas the in vitro experiments showed that $\mathrm{C} 3$ can affect directly the growth of neurites from retinal cells, it is likely that the effects we observed after application of $\mathrm{C} 3$ to the optic nerve in vivo are more complex. In some C3-treated animals, the crush zone was constricted compared with controls (Fig. 8b), suggesting that C3 may affect non-neuronal cells such as fibroblasts and astrocytes. Also, C3 is known to affect cell migration (Hall, 1998) and could influence macrophage invasion in the injured nerve. The effects of $\mathrm{C} 3$ on astrocytes and macrophages need be further examined both in vivo and in vitro to better understand the implications of $\mathrm{C} 3$ treatment for stimulating axon growth in vivo.

$\mathrm{C} 3$ is a $24 \mathrm{kDa}$ protein, and, although it may efficiently enter transected axons, growing or mature axons may not take up C3 very efficiently. The inability of intact growing axons to take up C3 may explain why the robust regeneration that we observed was not sustained for longer distances. It is known that injured axons take up exogenously applied retrograde tracers such as Fluorogold, but intact axons do not. Our interpretation of our results is that C3 has a dramatic but short-lived effect on RGC axons because it is taken up immediately after axon transection but is not taken up by axons once they begin to regenerate. Antagonists of Rho activity that can cross the plasma membrane of growing axons may improve the extent of regeneration. Also, it will be interesting to test $\mathrm{C} 3$ in spinal cord models of axon injury in which axon growth can be almost an order of magnitude greater that that observed in injured optic nerve after treatment with IN-1 antibody (Bartch et al., 1995). Nonetheless, our data of C3 treatment of injured optic nerve provide compelling evidence that C3 can promote neurite growth on inhibitory substrates in vitro and helps to overcome growth inhibition in vivo.

\section{REFERENCES}

Ajemain A, David S (1994) Tenascin in the injured rat optic nerve and in non-neuronal cells in vitro: potential role in neural repair. J Comp Neurol 340:233-242.

Albertinazzi C, Gilardelli D, Paris S, Longhi R, deCurtis, I (1998) Overexpression of a neural-specific Rho family GTPase, cRac1B, selectively induced enhances neuritogenesis and neurite branching in primary neurons. J Cell Biol 142:815-825.

Bandtlow CE, Schmidt MF, Hassinger TD, Schwab ME, Kater SB (1993) Role of intracellular calcium in NI-35-evoked collapse of neuronal growth cones. Science 259:80-83.

Bartsch U, Bandtlow CE, Schnell L, Bartsch S, Spillmann AA, Rubin BP, Hillenbrand R, Montag D, Schwab ME, Schachner M (1995) Lack of evidence that myelin-associated glycoprotein is a major inhibitor of axonal regeneration in the CNS. Neuron 15:1375-1381.

Berkelaar M, Clarke DB, Wang YC, Bray GM, Aguayo AJ (1994) Axotomy results in delayed death and apoptosis of retinal ganglion cells in adult rats. J Neurosci 14:4368-4374.

Berry M, Carlile J, Hunter A (1996) Peripheral nerve explants grafted into the vitreous body of the eye promote the regeneration of retinal ganglion cell axons severed in the optic nerve. J Neurocytol 25:147-170.
Bregman B, Kunkeel-Bagden E, Schnell L, Dai HN, Gao D, Schwab ME (1995) Recovery from spinal cord injury mediated by antibodies to neurite growth inhibitors. Nature 378:498-501.

Bregman BS, Broude E, McAtee M, Kelleey MS (1998) Transplants and neurotrophic factors prevent atrophy of mature CNS neurons after spinal cord injury. Exp Neurol 149:13-27.

Cai D, Shen Y, DeBellard M, Tang S, Filbin MT (1999) Prior exposure to neurotrophins blocks inhibition of axonal regeneration by MAG and myelin via a cAMP-dependent mechanism. Neuron 22:89-101.

Caroni P, Schwab ME (1988) Two membrane protein fractions from rat central myelin with inhibitory properties for neurite growth and fibroblast spreading. J Cell Biol 106:1281-1288.

Cheng H, Cao Y, Olson L (1996) Spinal cord repair in adult paraplegic rats: partial restoration of hind limb function. Science 273:510-513.

Collins BE, Yang LJ-S, Mukhopadhyay G, Filbin MT, Kiso M, Hasegawa A, Schnaar RL (1997) Sialic acid specificity of myelin-associated glycoprotein binding. J Biol Chem 272:1248-1255.

Daniels RH, Hall PS, Bokoch GM (1998) Membrane targeting of p21activated kinase 1 (PAK1) induces neurite outgrowth from PC12 cells. EMBO J 17:754-764.

David S, Aguayo AJ (1981) Axonal elongation into peripheral nervous system "bridges" after central nervous system injury in adult rats. Science 214:931-933.

David S, Braun PE, Jackson JL, Kottis V, McKerracher L (1995) Laminin overrides the inhibitory effects of PNS and CNS myelin-derived inhibitors of neurite growth. J Neurosci Res 42:594-602.

Davies SJA, Field PM, Raisman G (1994) Long interfascicular axon growth from embryonic neurons transplanted into adult myelinated tracts. J Neurosci 14:1596-1612.

Davies SJA, Fitch MT, Memberg SP, Hall AK, Raisman G, Silver J (1997) Regeneration of adult axons in white matter tracts of the central nervous system. Nature 390:680-683.

Dillon ST, Feig LA (1995) Purification and assay of recombinant C3 transferase. In: Methods in enzymology, Vol 256, Small GTPases and their regulators, Part B, Rho family (Balch WE, Der CJ, Hall A, eds), pp 174-184. Toronto: Academic.

Dong J-M, Leung T, Manser E, Lim L (1998) cAMP-induced morphological changes are counteracted by the activated RhoA small GTPase and the Rho kinase ROK $\alpha$. J Biol Chem 272:22554-22562.

Fournier AE, McKerracher L (1997) Expression of specific tubulin isotypes increases during regeneration of injured CNS neurons, but not after the application of brain-derived neurotrophic factor (BDNF). J Neurosci 17:4623-4632.

Hall A (1998) Rho GTPases and the actin cytoskeleton. Science 279:509-514.

Hutchens JA, Hoyle HD, Turner FR, Raff EC (1997) Structurally similar Drosophila $\alpha$-tubulins are functionally distinct in vivo. Mol Biol Cell 8:481-500.

Jalink K, van Corven EJ, Hengeveld T, Morii N, Narumiya S, Moolenaar WH (1994) Inhibition of lysophosphatidate-and thrombin-induced neurite retraction and neuronal cell rounding by ADP ribosylation of the small GTP-binding protein Rho. J Cell Biol 126:801-810.

Jin Z, Strittmatter SM (1997) Rac1 mediates collapsin-1-induced growth cone collapse. J Neurosci 17:6256-6263.

Katoh H, Aoki J, Ichikawa A, Negishi M (1998) p160 RhoA-binding kinase ROK $\alpha$ induces neurite retraction. J Biol Chem 273:2489-2492.

Keirstead HS, Hasan SJ, Muir GD, Steeves JD (1992) Suppression of the onset of myelination extends the permissive period for the functional repair of embryonic spinal cord. Proc Natl Acad Sci USA 89:11664-11668.

Kobayashi NR, Fan J, Giehl KM, Bedard AM, Weigand SJ, Tetzlaff W (1997) BDNF and NT-4/5 prevent atrophy of rat rubrospinal neurons after cervical axotomy, stimulate GAP-43 and T $\alpha 1$ tubulin mRNA expression, and promote axonal regeneration. J Neurosci 17:9583-9595.

Kozma R, Sarner S, Ahmed S, Lim L (1997) Rho family GTPases and neuronal growth cone remodeling: relationship between increased complexity induced by $\mathrm{Cdc} 42 \mathrm{Hs}$, Rac1, and acetylcholine and collapse induced by RhoA and lysophophatidic acid. Mol Cell Biol 17:1201-1211.

Kuhn TB, Schmidt MF, Kater SB (1995) Laminin and fibronectin guideposts signal sustained but opposite effects to passing growth cones. Neuron 14:275-285.

Kuhn TB, Brown MD, Wilcox CL, Raper JA, Bamburg JR (1999) Myelin and collapsin-1 induce motor neuron growth cone collapse through 
different pathways: inhibition of collapse by opposing mutants of Rac1. J Neurosci 19:1965-1975.

Lang P, Gesbert F, Delespine-Carmagnat M, Stancou R Pouchelet M, Bertoglio J (1996) Protein kinase A phosphorylation of RhoA mediates the morphological and functional effects of cyclic AMP in cytotoxic lymphocytes. EMBO J 15:510-519.

Laudanna C, Campbell JJ, Butcher EC (1996) Role of Rho in chemoattractant-activated leukocyte adhesion through integrins. Science 271:981-983.

Li M, Shibata A, Li C, Braun PE, McKerracher L, Roder J, Kater SB, David S (1996) Myelin-associated glycoprotein inhibits neurite/axon growth and causes growth cone collapse. J Neurosci Res 46:404-414.

Luo L, Liao J, Jan LY, Jan YN (1994) Distinct morphogenetic functions of similar small GTPases: Drosophila Drac1 is involved in axonal outgrowth and myoblast fusion. Genes Dev 8:1787-1802.

Luo L, Hensch TK, Ackerman L, Barbel S, Jan YN (1996) Differential effects of the Rac GTPase on Purkinje cell axons and dendritic spines. Nature 379:837-840.

Mackay DJG, Nobes CD, Hall A (1996) The Rho's progress: a potential role during neuritogenesis for the Rho family GTPases. Trends Neurosci 18:496-501.

Mason CA, Wang L-C (1997) Growth cone form is behavior-specific and, consequently, position-specific along the retinal axon pathway. J Neurosci 17:1086-1100.

McKeon RJ, Schreiber RC, Rudge JS, Silver J (1991) Reduction of neurite outgrowth in a model of glial scarring following CNS injury is correlated with the expression of inhibitory molecules on reactive astrocytes. J Neurosci 11:3398-3411.

McKerracher L, David S, Jackson JL, Kottis V, Dunn R, Braun PE (1994) Identification of myelin-associated glycoprotein as a major myelin-derived inhibitor of neurite outgrowth. Neuron 13:805-811.

Mohajeri MH, Bartsch U, van der Putten H, Sansug G, Mucke L, Schachner M (1996) Neurite outgrowth on non-permissive substrate in vitro is enhanced by ectopic expression of the neural adhesion molecule L1 by mouse astrocytes. Eur J Neurosci 8:1085-1097.

Mukhopadhyay G, Doherty P, Walsh FS, Crocker PR, Filbin MT (1994) A novel role for myelin-associated glycoprotein as an inhibitor of axonal regeneration. Neuron 13:805-811.

Narito M, Narumiya S (1995) Preparation of native and recombinant Clostridium botulinum C3 ADP-ribosyltransferase and identification of Rho proteins by ADP-ribosylation. In: Methods in enzymology, Vol 256, Small GTPases and their regulators, Part B, Rho family (Balch WE, Der CJ, Hall A, eds), pp 96-206 Toronto: Academic.

Nishiki T, Narumiya S, Morrii N, Yamamoto M, Fujiwara M, Kamata Y, Sakaguchi G, Kozak, S (1990) ADP-riblsylation of the rho/rac proteins induces growth inhibition, neurite outgrowth and acetylcholine esterase in cultured PC-12 cells. Biochem Biophys Res Commun 167:265-272.

Nobes CD, Hall AR (1995) Rho, Rac, and Cdc42 GTPases regulate assembly of multimolecular focal complexes associated with actin stress fibers, lamellipodia, and filopodia. Cell 1995 81:53-62.

Paulsson M, Lindblom A (1994) Cell biology: a laboratory handbook, Vol 1 (Celis JE, ed), pp 589-594. New York: Academic.

Qiu RG, Chen J, McCormick F, Symons M (1995) A role for Rho in Ras transformation. Proc Natl Acad Sci USA 92:11781-11785.

Renaudin A, Lehmann M, Girault, J-A, McKerracher L (1998) Organization of point contacts in neuronal growth cones. J Neurosci Res 55:458-471.

Ridley AJ, Hall A (1992) The small GTP-binding protein Rho regulates the assembly of focal adhesions and actin stress fibres in response to growth factors. Cell 70:389-399.

Rubin BP, Spilllmann AA, Bandtlow CE, Hillenbrand R, Keller F, Schwab ME (1995) Inhibition of PC12 cell attachment and neurite outgrowth by detergent solubilized CNS myelin proteins. Eur J Neurosci 7:2524-2529.

Rubin EJ, Gill DM, Boquet P, Popoff MR (1988) Functional modification of a 21-kilodalton G protein when ADP-ribosylated by exoenzyme C3 of Closteridium botulinum. Mol Cell Biol 8:418-426.

Santos MF, McCormack SA, Okolicany J, Zheng Y, Johnson LR Tigyi G (1997) The small molecular weight GTPase Rho is important for mucosal wound healing in vitro. J Clin Invest 100:216-225.

Sawai H, Clarke DB, Kittlerova P, Bray GM, Aguayo AJ (1996) Brain- derived neurotrophic factor and NT-4/5 stimulate the growth of axonal branches from regenerating retinal ganglion cells. J Neurosci 16:3887-3894.

Schafer M, Fruttiger M, Montag D, Schachner M, Martini R (1996) Disruption of the gene for the myelin-associated glycoprotein improves axonal regrowth along myelin in C57BL/Wlds mice. Neuron 16:1107-1113.

Schlaepfer DD, Hanks SK, Hunter T, van der Geer P (1996) Integrinmediated signal transduction linked to Ras pathway by GRB2 binding to focal adhesion kinase. Nature 372:786-791.

Schnell L, Schwab ME (1990) Axonal regeneration in the rat spinal cord produced by an antibody against myelin-associated neurite growth inhibitors. Nature 343:269-272.

Schnell L, Schneider R, Kolbeck R, Barde Y-A, Schwab ME (1994) Neurotrophin-3 enhances sprouting of corticospinal tract during development and after adult spinal cord lesion. Nature 367:170-173.

Schwab ME, Kapf hammer JP, Bandtlow CE (1993) Inhibitors of neurite outgrowth. Annu Rev Neurosci 16:565-595.

Sebok A, Nusser N, Debreceni B, Guo Z, Santos MF, Szeberenyi J, Tigyi G (1999) Different roles for RhoA during neurite initiation, elongation, and regeneration in PC12 cells. J Neurochem 73:949-960.

Sefton MV, Brown LR, Langer RS (1984) Ethylene-vinyl acetate copolymer microspheres for controlled release of macromolecules. J Pharmacol Sci 73:1859-1861.

Selles-Navarro I, Villegas-Perez MP, Salvador-Silva M, Ruiz-Gomez JM, Vidal-Sanz M (1996) Retinal ganglion cell death after different transient periods of pressure-induced ischemia and survival intervals. Invest Ophthalmol Vis Sci 37:2002-2014.

Shibata A, Wright MV, David S, McKerracher L, Braun PE, Kater SB (1998) Unique responses of differentiating neuronal growth cones to inhibitory cues presented by oligodendrocytes. J Cell Biol 142:191-202.

Song H, Ming G, He Z, Lehmann M, McKerracher L, Tessier-Lavigne M, Poo M (1998) Conversion of growth cone responses from repulsion to attraction by cyclic nucleotides. Science $281: 1515-1518$.

Threadgill R, Bobb K, Ghosh A (1997) Regulation of dendritic growth and remodeling by Rho, Rac, Cdc42. Neuron 19:625-634.

Tigyi G, Fischer DJ, Sebok A, Marshall F, Dyer DL, Miledi R (1996a) Lysophophatidic acid-induced neurite retraction in PC12 cells: neuriteprotective effects of cyclic AMP signaling. J Neurochem 66:549-558.

Tigyi G, Fischer DJ, Sebok A, Yang C, Dyer DL, Miledi R (1996b) Lysophosphatidic acid-induced neurite retraction in PC12 cells: control by phosphoinositide- $\mathrm{Ca}^{+}{ }^{2}$ signaling and Rho. J Neurochem 66:537-548.

Torigoe K, Lundborg G (1998) Selective inhibition of early axonal regeneration by myelin-associated glycoprotein. Exp Neurol 150:254-262.

Udagawa T, McIntyre BW (1996) ADP-ribosylation of the G protein rho inhibits integrin regulation of tumor cell growth. J Biol Chem 271:12542-12548.

van Leeuwen FN, Kain HET, van der Kammen RA, Michiels F, Kranenburg OW, Collard JG (1997) The guanine nucleotide exchange factor Tiam1 affects neuronal morphology; opposing roles for the small GTPases Rac and Rho. J Cell Biol 139:797-807.

Vidal-Sanz M, Bray GM, Villegas-Perez MP, Thanos S, Aguayo AJ (1987) Axonal regeneration and synapse formation in the superior colliculus by retinal ganglion cells in the adult retina. J Neurosci 7:2894-2909.

Villegas-Perez MP, Vidal-Sanz M, Bray GM, Aguayo AJ (1988) Influences of peripheral nerve grafts on the survival and regrowth of axotomized retinal ganglion cells in adult rats. J Neurosci 8:265-280.

Villegas-Perez MP, Vidal-Sanz M, Rasminsky M, Bray GM, Aguayo AJ (1993) Rapid and protracted phases of retinal ganglion cell loss follow axotomy in the optic nerve of adult rats. J Neurobiol 24:23-36.

Wictorin K, Brundin P, Gustavii B, Lindvall O, Bjorklund A (1990) Reformation of long axon pathways in adult rat central nervous system by human forebrain neuroblasts. Nature 347:556-558.

Yang LJ-S, Zeller CB, Shaper NL, Kiso M, Hasegawa A, Shapiro RE, Schnaar RL (1996) Gangliosides are neuronal ligands for myelinassociated glycoprotein. Proc Natl Acad Sci USA 93:814-818.

Zipkin IL, Kindt RM, Kenyon CJ (1997) Role of a new rho family member in cell migration and axon guidance in $C$. elegans. Cell 90:883-894. 